УДК 373.21[37.07:371.12](477)

https://doi.org/10.33296/2707-0255-9(17)-07

https://orcid.org/0000-0002-7954-2739*

https://orcid.org/0000-0002-5162-5831**

\author{
Марія АСТАХОВА*, \\ кандидат педагогічних наук, доцент \\ кафедри педагогіки, іноземної \\ філології та перекладу \\ Харківського національного \\ економічного університету \\ імені Семена Кузнеця, \\ м. Харків, Україна \\ Ольга ШЕВАНДІНА**, \\ магістрант Харківського \\ національного економічного \\ університету імені Семена Кузнеця, \\ завідувач дошкільного навчального \\ закладу № 87, м. Харків, Україна,
}

\title{
УПРАВЛІННЯ ФОРМУВАННЯМ ЛІДЕРСЬКОЇ КОМПЕТЕНТНОСТІ ПЕДАГОГІЧНИХ ПРАЦІВНИКІВ ЗАКЛАДУ ДОШКІЛЬНОЇ ОСВІТИ
}

Анотація. Сучасний розвиток суспільства висуває нові вимоги до педагога, потребує розвитку його духовного та лідерського потенціалу. Зараз зростає попит на креативну, нестандартно мислячу особистість, яка наділена силою волі, має лідерські якості, розвинений «емоційний інтелект» та готова вести колектив за собою. Саме особистісне і професійне становлення педагогалідера забезпечить розвиток освіти як європейської соціальної інституції. Значну роль у розвитку загальнопрофесійної компетентності педагога закладу дошкільної освіти відіграє формування лідерської компетентності, а завдання керівника закладу освіти, в свою чергу, ефективно управляти цим процесом.

У статті розглянуті погляди науковців на зміст поняття «професійна компетентність» та «лідерська компетентність». Розкрито сутнісні характеристики лідерства в освіті. Охарактеризовано розвиток професійно значущих лідерських якостей та виокремлено соціально-психологічні фактори, які впливають на професійну діяльність педагога-лідера.

Проаналізовано освітній процес як об'єкт управління та управління освітньою діяльністю закладу дошкільної освіти в умовах реформування освіти в Україні. Визначено, що управління являе собою складний соціальноекономічний процес та реалізується через певні функції.

(C) Украӥнська інженерно-педагогічна академія

(С) ГО «Школа адаптивного управління соціально-педагогічними системами» (ㄱ Астахова М., Шевандіна О 
Особливу увагу приділено розкриттю структури процесу управління освітньою діяльністю закладу дошкільної освіти, який відтворює управлінський цикл та реалізується через загальні функції управління. Створено та досліджено складові системи управління лідерської компетентності та шляхи іiі формування, розроблено інструментарій визначення ефективності реалізації системи управління лідерської компетентності педагогічних працівників закладу дошкільної освіти.

Ключові слова: компетентність, професійна компетентність, лідер, лідерська компетентність, управління якістю освіти, система управління, заклад дошкільної освіти.

Вступ. Сучасний світ вимагає абсолютно нового ставлення до розуміння лідерства. Зміна поглядів на проблему дослідження пов'язана 3 розвитком суспільства, активним впровадженням комп’ютерних технологій і повсюдним використанням інтернету у всіх сферах людського життя. Глобалізація ринку праці та євроінтеграція вимагають нових організацій, в яких створюється ефективний робочий простір, здійснюється вдале керування людськими ресурсами та розвиток їхнього потенціалу. У сучасних умовах розвиток «м'яких навичок» (soft skills) в учасників освітнього процесу є невід'ємною складовою якісної освіти.

Комунікативні здібності, вміння співчувати, бути лідером, розвивати лідерські якості, гнучкість та відповідальність тощо - все, що відрізняє людину від штучного інтелекту й дозволяє гармонійно взаємодіяти зі світом [9].

Україна обрала євроінтеграційний шлях розвитку, який передбачає реформування у багатьох сферах людської діяльності. Цей процес охопив i освітню галузь. На сучасному етапі розвитку стало зрозуміло, що освітню діяльність потрібно спрямовувати не стільки на отримання практичних знань, умінь, навичок, скільки на формування всебічно розвиненої особистості, яка оволоділа ключовими компетентностями та здатністю вчитися протягом усього життя.

Аналіз останніх досліджень і публікацій. Різні аспекти лідерства завжди були центром теоретичного аналізу та практичних досліджень багатьох 
Електронне наукове фахове видання «Адаптивне управління: теорія і практика. Серія "Педагогіка"

науковців. Значну кількість наукових праць присвячено обгрунтуванню змісту компетентнісного підходу в освіті: С. Бондар, С. Гончаренко, Н. Ничкало, О. Овчарук та ін. Вагомий внесок у розробку вітчизняної теорії лідерства зробили такі вчені, як І. Волков, Н. Жеребова, Р. Кричевський, В. Лозниця, Б. Паригін, Л. Уманський Ф. Хміль та ін. Серед зарубіжних дослідників слід відзначити праці Д. Адаіра, I. Адізеса, У. Бенніса, М. Брауна, В. Врума, К. Левіна, Д. МакГрегора, та ін.

Bсе активніше відбувається обгрунтування теоретичних засад формування лідерської компетентності у педагогів (Р. Блейк, А. Болдвін, Д. Дьюї, О. Киричук, Р. Лайкерт, О. Лозинський та ін.), однак науковцями недостатньо уваги приділено дослідженню методів та шляхів формування лідерської компетентності працівників закладів дошкільної освіти.

Метою статті $\epsilon$ аналіз, обгрунтування та розробка моделі управління формуванням лідерської компетентності педагогічних працівників закладу дошкільної освіти.

Виклад основного матеріалу. Переважна більшість дослідників трактують поняття «компетентність» через особистісні якості. Так, І. Зимня визначає компетентність як «актуалізовану, інтегративну, таку, що базується на знаннях, інтелектуально й соціокультурно зумовлену особистісну якість, яка проявляється в діяльності, поведінці людини, у іiі взаємодії з іншими людьми під час вирішення різноманітних завдань». Така якість набуває розвитку в освітньому процесі і стає його результатом. При цьому до характеристик компетентності вчена відносить: готовність до прояву компетентності (мотиваційний аспект); володіння знаннями змісту компетентності (когнітивний аспект); досвід прояву компетентності в різноманітних стандартних і нестандартних ситуаціях (поведінковий аспект); ставлення до змісту компетентності й об’єкта ii застосування (ціннісно-смисловий аспект); 
Електронне наукове фахове видання «Адаптивне управління: теорія і практика. Серія «Педагогіка" Випуск 9(17), 2020

емоційно-вольову регуляцію процесу i результату прояву компетентності [5, c. 13].

У працях Г. Селевка знаходимо компетентність - це «інтегральна якість особистості, що виявляється в загальній здатності та готовності до діяльності, яка базується на знаннях і досвіді, здобутих у процесі навчання і соціалізації й орієнтованих на самостійну й успішну участь у діяльності» [15, с. 139].

Значна кількість дослідників поділяє думку щодо розуміння компетентності як результату набуття компетенцій. За визначенням групи науковців з Інституту педагогічної освіти і освіти дорослих НАПН України, «компетентність - це результат набуття людиною компетенцій, які дають їй змогу якісно виконувати трудові функції, успішно засвоювати знання, взаємодіяти з іншими людьми в різних ситуаціях, швидко адаптуватися до змін у професійній діяльності, набувати соціальної самостійності» [7, с. 17]. Спираючись на це визначення розуміємо, що набуття компетентностей особистістю впливає на професійну діяльність, а рівень їх розвиненості визначає успішність в професійній діяльності.

Для людей різних професій характерні особливі, специфічні прояви ключових компетентностей, які формують професійну компетентність та впливають на рівень професійної діяльності. В основі концепції професійної компетентності лежить ідея виховання компетентного працівника, який не лише має необхідні знання, професіоналізм, але й уміє діяти адекватно у відповідних ситуаціях, застосовуючи ці знання, й бере на себе відповідальність за певну діяльність. В умовах конкуренції основними пріоритетами фахівця 3’являються вміння пристосовуватися до швидких змін і нових потреб ринку праці, бути освіченим щодо інформації, уміти пї аналізувати, активно діяти, швидко приймати рішення й навчатися упродовж всього життя [16].

Зарубіжні дослідники зазначають, що «професійна компетентність - це набір моделей професійної поведінки, яку працівник повинен використовувати 
Електронне наукове фахове видання «Адаптивне управління: теорія і практика. Серія "Педагогіка" Випуск 9(17), 2020

у межах своєї посади, дає можливість кваліфіковано проводити діяльність та компетентно виконувати свої завдання і функції спрямованих на досягнення певних стандартів у професійній галузі чи конкретній діяльності» [19].

Логіка нашого дослідження потребує аналізу поняття «лідер». Так, лідер (від англ. leader - ведучий, перший, такий, що йде попереду) - особа в окремій групі (організації), що має значний, визнаний авторитет, вплив, який виявляється як дії, що управляють. Лідер - член групи, за яким вона визнає право приймати відповідальні рішення в значущих для неї ситуаціях, тобто найавторитетніша особа, що відіграє центральну роль в організації спільної діяльності й регулюванні взаємин у групі [18, с. 489]. Український психолог В. Татенко зазначає, що «бути лідером - значить вказувати шлях іншим найліпший, найкоротший, найбезпечніший». На його думку, лідер «не лише веде i направляє своїх послідовників, але й прагне вести їх за собою, а послідовники не лише йдуть за лідером, але й хочуть іти за ним» [16, с. 12].

Над проблемою лідерства працювало багато вчених, які пропонували різні визначення цього поняття, серед яких чимало авторів, що у визначенні поняття лідерства намагалися сформулювати той особливий компонент, який вносить сам лідер.

Лідерство - це здатність здійснювати вплив на окремих осіб і групи, спрямовуючи їх зусилля на досягнення цілей організації [11, с. 464], тобто забезпечувати ефективну взаємодію членів групи. Саме ефективне лідерство використовує нові джерела влади і забезпечує іiі нові позитивні наслідки: прихильність до організації і готовність до змін [1, с. 357].

Р.-Л. Дафт (Richard L. Daft) трактує лідерство як взаємовідносини між лідером і членами групи, які чинять вплив один на одного і спільно прагнуть реальних змін і досягнення результатів, що відбивають загальну мету. Дж. Teppi (J. Terry) вважає, що лідерство - це вплив на групи людей, який спонукає їх до досягнення спільної мети. Р. Танненбаум (R. Tannenbaum), I. Вешлер (I. 
Електронне наукове фахове видання «Адаптивне управління: теорія і практика. Серія «Педагогіка»

Weschler) i Ф. Масарик (F. Masaryk) визначають лідерство як міжособистісну взаємодію, яка виявляється в конкретній ситуації на основі комунікативного процесу і спрямована на досягнення мети.

Під лідерством розуміється спроможність впливати на окремі особистості та соціальні групи, трудові колективи, спрямовувати їхні зусилля на досягнення мети організації, фірми, підприємства.

Розвиток лідерства - це цілеспрямований процес формування відповідних якостей та навичок. Даний аспект проблеми управління лідерством в організації більшою чи меншою мірою враховує можливість формування i розвитку лідерських якостей шляхом навчання і самонавчання. Лідерські якості являють собою певну складову особистісних якостей людини, тому, впливаючи на ці компоненти особистості, на думку Е. Помиткіна, ми певним чином втручаємося в загальну систему особистісних якостей людини [13].

Лідерами не народжуються. Становлення лідера - це певний процес, під час якого в особисті формується лідерська компетентність. Лідерська компетентність педагогічного працівника закладу дошкільної освіти - це якість особистості педагога, формування якої потребує, з одного боку, певних зусиль 3 боку педагогічного працівника, з іншого боку, створення умов, що будуть сприяти формуванню відповідної компетентності.

На розвиток професійно значущих лідерських якостей впливає ряд соціально-психологічних факторів, які впливають на педагогічного працівника $\mathrm{i}$ його діяльність. Так, І. Морозов виділяє технологічний, творчий, етичний i регулятивний фактори. Спираючись на класифікацію I. Морозова, сформулюємо фактори, що впливають на формування лідерських якостей педагогічних працівників закладу дошкільної освіти та розглянемо детально кожен з них:

1. Технологічний фактор. Зміни пов'язані з появою сучасних технологій, тягнуть за собою пред’явлення жорстких вимог за результат своєї діяльності до 
Електронне наукове фахове видання «Адаптивне управління: теорія і практика. Серія «Педагогіка" Випуск 9(17), 2020

фахівців в різних сферах. Так, педагогічний працівник закладу дошкільної освіти повинен бути готовий до вирішення складних завдань, пов'язаних 3 професійною діяльністю, володіти високим рівнем теоретичної і практичної підготовки, при цьому постійно підвищувати рівень професійної компетентності.

2. Творчий фактор. Сучасний педагогічний працівник закладу дошкільної освіти повинен знаходити креативні рішення нових підходів, привносити нові ідеї, проявляти творчий підхід і лідерську активність при прийнятті різних рішень.

3. Етичний фактор характеризується бездоганністю виконання взятих на себе зобов'язань у всіх сферах професійного становлення особистості. Сучасний педагогічний працівник закладу дошкільної освіти повинен відрізнятися високим рівнем відповідальності, моральної культури, порядністю, чуйністю, здатністю цінувати інших людей.

4. Регулятивний фактор. Методи управління вже давно застаріли і не відповідають сучасним стандартам управління. 3 цієї причини сучасний педагогічний працівник закладу дошкільної освіти повинен використовувати такі навички i прийоми ефективного лідерства, які не створюються за допомогою прямих вказівок відносин влади і підпорядкування між людьми, а формують гармонійні відносини за допомогою навіювання ентузіазму, заохочення, відданості, ввічливості, поваги [12].

Візьмемо за критерій ефективності діяльності педагогічних працівників закладу дошкільної освіти ці фактори, виділимо наступні групи якостей, необхідні для успішної професійної діяльності та формування лідерської компетентності педагогічних працівників закладу дошкільної освіти: загальнопрофесійні (якості, властиві для ефективного здійснення освітньої діяльності); творчі якості, які характеризуються умінням особистості розвивати нові ідеї $\mathrm{i}$ привносити їх у діяльність групи; моральні якості, пов'язані 3 високим 
Електронне наукове фахове видання «Адаптивне управління: теорія і практика. Серія "Педагогіка" Випуск 9(17), 2020

моральний рівнем особистості і їі достоїнствами; комунікативні якості - уміння особистості знаходити спільні точки дотику з оточуючими і переконувати в своїй правоті [8].

Виділення груп лідерських якостей дозволяє визначити напрямки для розробки шляхів забезпечення розвитку лідерської компетентності педагогічних працівників і цілеспрямовано вибудувати план їх розвитку.

Відповідно до Закону України «Про освіту» (далі Закон) кожен заклад освіти має право самостійно приймати рішення з будь-яких питань у межах своєї автономії, визначеної цим Законом, спеціальними законами та/або установчими документами У Законі також зазначено, що керівник закладу освіти в межах наданих йому повноважень: організовує діяльність закладу освіти, а також забезпечує організацію освітнього процесу та здійснення контролю за виконанням освітніх програм, а якість освітньої діяльності - це рівень організації, забезпечення та реалізації освітнього процесу, що забезпечує здобуття особами якісної освіти та відповідає вимогам, встановленим законодавством та/або договором про надання освітніх послуг [4]. Спираючись на норми Закону розуміємо, що на керівника закладу дошкільної освіти покладено високу відповідальність за організацію роботи закладу дошкільної освіти та за розвиток персоналу.

Важливим в нашому дослідженні є бачення науковця Г. Сльникової на поняття управління, а саме: «управління - це особливий вид людської діяльності в умовах постійних змін внутрішнього та зовнішнього середовища, який забезпечує цілеспрямований вплив на керовану систему для збереження $\mathrm{i}$ впорядкування ii в межах наданих параметрів на основі закономірностей ii розвитку та дії механізмів самоуправління» [3].

На думку науковців М. Мескона, Ф. Хедоурі та М. Альберта, «управління - це процес планування, організації, мотивації і контролю, який необхідний для того, щоб сформулювати і досягти цілей організації» [12, с. 68]. Процес 
Електронне наукове фахове видання «Адаптивне управління: теорія і практика. Серія "Педагогіка" Випуск 9(17), 2020

управління здійснюється шляхом реалізації певних функцій. Функція - це вид певної діяльності, змінна величина (залежна від другої величини), яка характеризує роль соціального утворення [2].

Сьогодні немає єдиної класифікації функцій управління. Проте більшість авторів схильні виокремлювати загальні (основні, операційні) функції, які засвідчують циклічність діяльності.

Серед них Б. Гаєвський називає передбачення, контроль, планування, аналіз, координацію, програмування; В. Афанасьєв - організацію, контроль, виконання, регулювання; М. Поташник - організацію, контроль, планування, керівництво; Ю. Конаржевський - аналіз, планування, організацію, контроль, регулювання; М. Мескон - планування, організацію, мотивацію, контроль.

Дійсно, загальні функції управління, послідовно змінюючи одна одну, утворюють управлінський цикл: аналіз - планування - організація - контроль регулювання. Освітній процес як об’єкт управління знаходиться в центрі уваги всіх керівників закладів дошкільної освіти. Управління освітнім процесом у закладі дошкільної освіти становить собою складну систему взаємодій: адміністрація - вихователь, адміністрація - вихованець, вихователь вихованець, адміністрація - вихователь - вихованці - батьки та громадськість тощо. За своєю структурою процес управління освітньою діяльністю закладу дошкільної освіти відтворює управлінський цикл та реалізується через загальні функції управління до яких відноситься: аналіз, планування, організацію, контроль, координацію та регулювання [10, с.38].

Як зазначає Л. Карамушка, «система управління - це сукупність керованого об’єкта або процесу і пристрою керування, до якого належить комплекс засобів прийому, збору і передачі інформації та формування сигналів i команд». При цьому дія системи управління направлена на поліпшення i підтримку роботи процесу або об’єкту. В деяких випадках без автоматизованої системи управління взагалі неможливо вирішення завдання в силу складності 
Електронне наукове фахове видання «Адаптивне управління: теорія і практика. Серія «Педагогіка"

процесу управління [6].

Процес реформування дошкільної освіти як складової освітньої галузі потребує оновлення змісту освітньої діяльності 3 урахуванням сучасних тенденцій розвитку України як демократичної держави. Важливою умовою оновлення дошкільної освіти $є$ пошук нових освітніх ідей, що сприятимуть підвищенню якості освітньої діяльності. Дошкільна освіта потребує появи педагог-лідерів, які поведуть за собою педагогічні колективи, організують вихованців, об’єднають батьківську спільноту.

У формуванні лідерської компетентності працівників закладу дошкільної освіти важливим фактором $\epsilon$ виявлення рівня сформованості окремих складових лідерської компетентності та проведення роботи спрямованої на якісне покращення цих показників.

У нашому дослідженні виділено групи якостей педагогічних працівників, які розглядаються, як складові лідерської компетентності, а саме: загальнопрофесійні, творчі, моральні, комунікативні.

Під час виявлення рівня загальнопрофесійних якостей педагогічних працівників необхідно було вивчити стан ведення ділової документації, організацію та проведення освітньої діяльності з дітьми, з батьками.

Для вивчення рівня сформованості лідерської компетентності доцільно проаналізувати стан ведення наступної документації: план освітньої діяльності (календарний, перспективний); щоденник педагога з підвищення професійного рівня; картотеку дидактичних ігор, методичних розробок (конспекти різних видів діяльності з дітьми тощо). Ці документи є обов’язковими для ведення керівником музичним, інструктором з фізкультури та керівником гуртка.

Під час виявлення рівня загальнопрофесійних якостей педагогічних працівників важливо було вивчити рівень проведення освітньої діяльності за освітніми лініями відповідно до нової редакції Базового компоненту дошкільної освіти. Для лідера-педагога важливо вміти знаходити креативні рішення, 
Електронне наукове фахове видання «Адаптивне управління: теорія і практика. Серія "Педагогіка" Випуск 9(17), 2020

привносити нові ідеї у власну професійну діяльність, проявляти творчий підхід і лідерську активність при прийнятті різних рішень.

Щоб оцінити рівень прояву творчих якостей педагогічних працівників доцільно провести тестування на виявлення загального рівня творчого потенціалу особистості педагогів. Моральні якості для лідера-педагога мають визначне значення. Для педагогічного працівника закладу дошкільної освіти важливо мати високий рівень відповідальності, моральної культури, порядність, чуйність, здатність цінувати інших людей. Також важливим проявом моральних якостей $\epsilon$ два фактори: «домінування-підпорядкування» та «дружелюбність-агресивність (ворожість)», які визначають загальне враження про людину в процесах міжособистісного сприйняття. Для того, щоб оцінити переважаючий тип відносин до людей в самооцінці та взаємооцінці, на нашу думку, доцільно було провести діагностику міжособистісних стосунків Т. Лірі.

Для лідера-педагога розвинені комунікативні якості, наприклад, знаходження спільної мови, здатність розуміти оточуючих, переконливо говорити і не ординарно мислити, важливі для налагодження доброзичливих взаємин у малій групі та формування власного авторитету.

У нашому дослідженні визначити рівень розвитку комунікабельних якостей педагогів допоміг тест «Комунікабельність» за методикою В. Ряховського. Вхідне тестування 3 одного боку слугувало підгрунтям для створення системи управління формуванням лідерської компетентності, 3 іншого боку - увібрало в себе усі функції управління освітньою діяльністю, являє собою складову системи управління. Тобто управлінський цикл та вхідне тестування взаємопов’язані складові.

Дотримуючись дослідження складових управлінського циклу, отримані результати вхідного тестування нами опрацьовано та ретельно проаналізовано для того, щоб виявити аспекти у діяльності педагогічних працівників, які потребують удосконалення.

(C) Украӥнська інженерно-педагогічна академія

(С) ГО «Школа адаптивного управління соціально-педагогічними системами» (C) Астахова М., Шевандіна О 
Електронне наукове фахове видання «Адаптивне управління: теорія і практика. Серія «Педагогіка»

Випуск 9(17), 2020

Наступною складовою системи управління $є$ шляхи формування лідерської компетентності, що реалізуються через комплекс заходів, які будуть сприяти підвищенню рівня професійної діяльності педагогів, а саме: цикл семінарів: «Стилі спілкування», «Техніка і культура мовлення»; «Імідж вихователя», «Вправи для самопідготовки»; практикуми для підвищення рівня комп’ютерної грамотності: «Електронні підручники - помічники в процесі підвищення рівня професійної діяльності», «Дистанційні освітні технології для дошкільнят», «Використання месенджерів в освітній діяльності», «Роль соціальних мереж у формуванні позитивного іміджу вихователя»; майстер-клас «Розробка Портфоліо, як складова підвищення самооцінки». На кінець дослідження нами здійснено за вхідною методикою аналіз вихідного рівня лідерської компетентності.

Усі складові утворюють систему управління лідерської компетентності педагогічних працівників закладу дошкільної освіти, яка представлена на рис. 1.

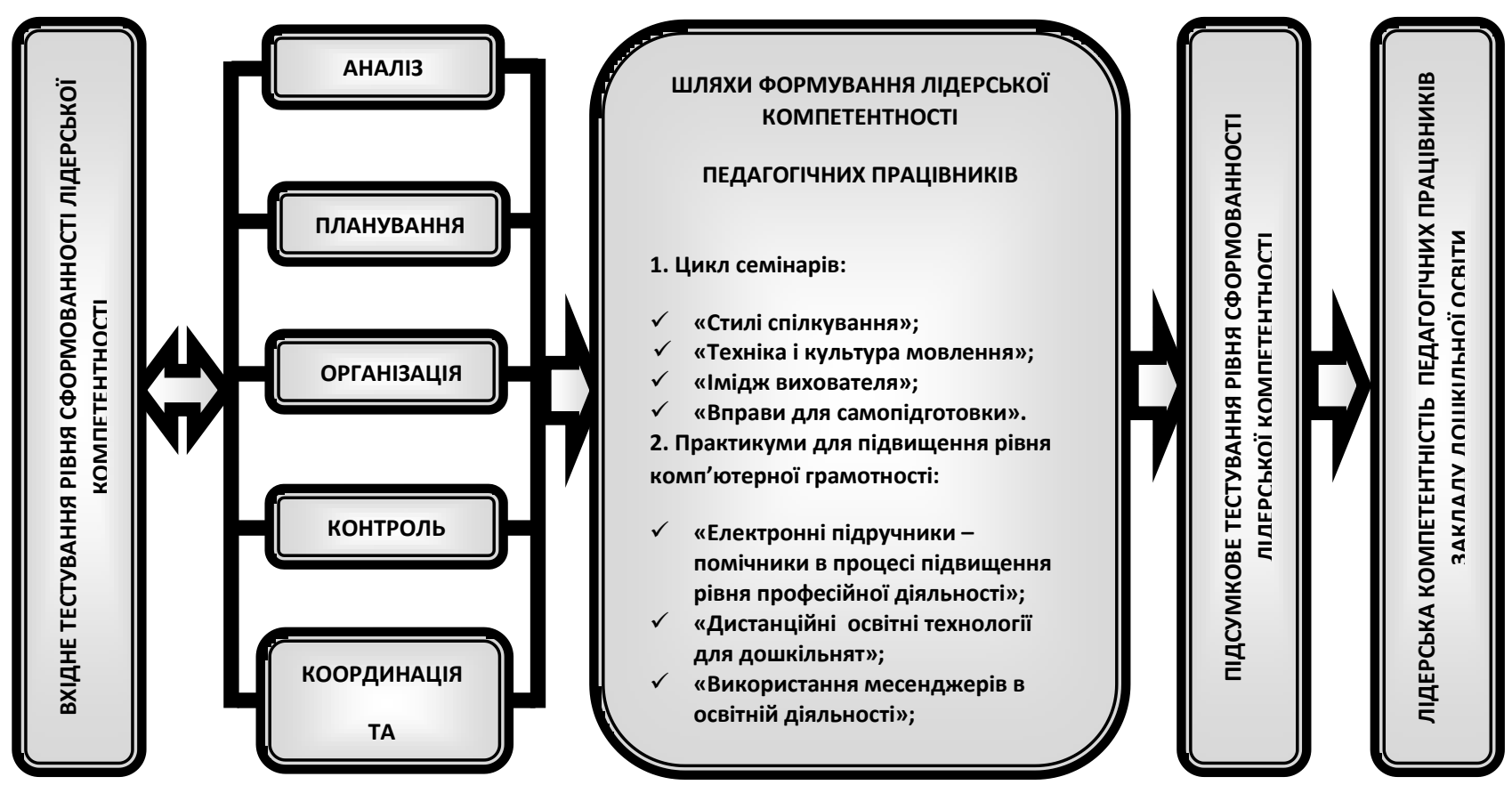

Рис1. Система управління формуванням лідерської компетентності педагогічних працівників закладу дошкільної освіти 
За результатами дослідження спостерігається позитивна динаміка усіх груп якостей, які формують лідерську компетентність педагогічних працівників. Що підтверджує ефективність запропонованої нами системи управління лідерської компетентності педагогічних працівників закладу дошкільної освіти.

Висновки. Реформування освітньої галузі потребує виховання людей нової формації, які не тільки є професіоналами своєї справи, але і здатні надихати людей навколо себе, активувати людській природній потенціал. Користуючись власним авторитетом спрямовувати діяльність групи для досягнення певної мети у професійній діяльності.

Для налагодження ефективної роботи 3 формування лідерської компетентності педагогічних працівників закладу дошкільної освіти, необхідно створити систему управління, яка через реалізацію управлінського циклу, виведе професійну діяльність кожного педагогічного працівника на якісно новий рівень.

Перспективи подальших досліджень. Результати дослідження не вичерпують всіх аспектів проблеми. Подальші дослідження необхідно спрямувати на розробку комплексно-цільової програми розвитку лідерського потенціалу здобувачів дошкільної освіти.

\section{СПИСОК ЛІТЕРАТУРИ}

1. Доронін А. В. Якісний розвиток функцій керівника колективу. Коммунальное хозяйство городов. Сб. научн. трудов. Вып. 87. К. : Техніка. 2009. C. 357-366.

2. Друкер П. Рынок: как выйти в лидеры. Практика и принципы: пер. с англ. М., 1992. С. 38.

3. Сльникова Г. В. Наукові основи розвитку управління загальною середньою освітою в регіоні. Х.: Крок, 1999. 303 с.

(C) Украӥнська інженерно-педагогічна академія

(С) ГО «Школа адаптивного управління соціально-педагогічними системами» (C Астахова М., Шевандіна О 
4. Закон України «Про освіту» від 05.09.17 № 2145-VIII URL: http://zakon2.rada.gov.ua/laws/show/2145-19.

5. Зимняя И. А. Ключевые компетенции - новая парадигма результата образования. Эксперимент и инноващии в школе. 2009. № 2. С. 7-14.

6. Карамушка Л. Принцип гуманізації управління як один 3 провідних принципів освітнього менеджменту. Освіта управління. 2002. № 4. С. 41-60.

7. Компетентнісний підхід до підготовки педагогів у зарубіжних країнах : теорія та практика : монографія / [Н. М. Авшенюк, Т. М. Десятов, та ін.]. Кіровоград: Імекс-ЛТД, 2014. 280 с.

8. Кон I. С. Социологическая психология М.: Московський психологосоциальний институт; Воронеж: НВО «МОДЕК», 1999. 560 с.

9. Лучанінова О. Адаптивний менеджмент в освіті: нова роль викладача сучасного закладу вищої освіти. Адаптивне управління: теорія $i$ практика. Серія Педагогіка, 7(13). 7 (13), 2019 URL: https://amtp.org.ua/index.php/journal/article/view/158/189

10. Мартинець Л. А. Управлінська діяльність керівника навчального закладу: навч. посібн. Вінниця, 2018. С.12-14.

11. Мескон М. Х. Основы менеджмента: пер. с англ. М.: «Дело», 1999. С. 464.

12. Морозов И. Е. Развитие лидерских качеств у студентов в процессе вузовского обучения: автореф. ... дис. канд. психол. наук: М., 2006. 28 с.

13. Помиткін Е. С. Психологічні аспекти проблеми виявлення та розвитку лідерських якостей особистості майбутнього професіонала. Творча особистість у системі неперервної професійної освіти: матеріали міжнар. наук. конфер. 16-17 травня 2000 р. С. 290-293.

14. Психологический словарь. Под ред. А. В. Петровского, М. Г. Ярошевского. М., 1990. 607 с. URL: https://ua.waykun.com/articles/u-liderapovinna-buti-visoka-komunikabelnist.php.

15. Селевко Г. Компетентности и их классификация. Народное образование. 2004. № 4. С. 138-143.

16. Тараненко I. Розвиток життєвої компетентності та соціальної інтеграції: досвід Європейських країн / за ред. Срмакова I. Г. // Кроки до компетентності та інтеграції в суспільстві. К.: «Контекст», 2000.

17. Татенко В. О. Лідер XXI / Leader XXI. Соціально-психологічні студії. К. : Корпорація, 2004. 198 с.

18. Чанышев А. Н. Аристотель / А. Н. Чанышев. 2-е изд., доп. М.: Мысль, 1987. $221 \mathrm{c}$.

19. Boyatzis R. The competent manager. New York: Wiley, 2005. 406 p.

20. McClelland D. C. Testing for competence rather than for intelligence. American Psychologist. 1973. №28. P. 1-14. 


\section{REFERENCES}

1. Doronin A. V. Yakisnyi rozvytok funktsii kerivnyka kolektyvu. Kommunalnoe khoziaistvo horodov. Sb. nauchn. trudov. Vыp. 87. K.: Tekhnika. 2009. S. 357-366.

2. Druker P. Rynok: kak vyyti v lidery. Praktika i printsipy: per. s angl. M., 1992. S. 38.

3. Ielnykova H. V. Naukovi osnovy rozvytku upravlinnia zahalnoiu serednoiu osvitoiu v rehioni. Kh.: Krok, 1999. 303 s.

4. Zakon Ukrainy «Pro osvitu» vid 05.09.17 № 2145-VIII URL: http://zakon2.rada.gov.ua/laws/show/2145-19.

5. Zimnyaya I. A. Klyuchevye kompetentsii - novaya paradigma rezultata obrazovaniya. Eksperiment i innovatsii v shkole. 2009. № 2. S. 7-14.

6. Karamushka L. Pryntsyp humanizatsii upravlinnia yak odyn z providnykh pryntsypiv osvitnoho menedzhmentu. Osvita upravlinnia. 2002. № 4. S. 41-60.

7. Kompetentnisnyi pidkhid do pidhotovky pedahohiv u zarubizhnykh krainakh : teoriia ta praktyka : monohrafiia / [N. M. Avsheniuk, T. M. Desiatov, ta in.]. Kirovohrad: Imeks-LTD, 2014. $280 \mathrm{~s}$.

8. Kon I. S. Sotsiologicheskaya psikhologiya M.: Moskovskiy psikhologosotsialniy institut; Voronezh: NVO «MODYeK», 1999. $560 \mathrm{~s}$.

9. Luchaninova O. Adaptyvnyi menedzhment v osviti: nova rol vykladacha suchasnoho zakladu vyshchoi osvity. Adaptyvne upravlinnia: teoriia i praktyka. Seriia Pedahohika, 7(13). 7 (13), 2019 URL: https://amtp.org.ua/index.php/journal/article/view/158/189

10. Martynets L. A. Upravlinska diialnist kerivnyka navchalnoho zakladu: navch. posibn. Vinnytsia, 2018. S.12-14. 464.

11. Meskon M. X. Osnovy menedzhmenta: per. s angl. M.: «Delo», 1999. S.

12. Morozov I. Ye. Razvitie liderskikh kachestv u studentov $\mathrm{v}$ protsesse vuzovskogo obucheniya: avtoref. ... dis. kand. psikhol. nauk: M., 2006. 28 s.

13. Pomytkin E. S. Psykholohichni aspekty problemy vyiavlennia ta rozvytku liderskykh yakostei osobystosti maibutnoho profesionala. Tvorcha osobystist $\mathrm{u}$ systemi neperervnoi profesiinoi osvity: materialy mizhnar. nauk. konfer. 16-17 travnia 2000 r. S. 290-293.

14. Psikhologicheskiy slovar. Pod red. A. V. Petrovskogo, M. G. Yaroshevskogo. M., 1990. 607 c. URL: https://ua.waykun.com/articles/ulidera-povinna-buti-visoka-komunikabelnist.php.

15. Selevko G. Kompetentnosti i ikh klassifikatsiya. Narodnoe obrazovanie. 2004. № 4. S. 138-143. 
16. Taranenko I. Rozvytok zhyttievoi kompetentnosti ta sotsialnoi intehratsii: dosvid Yevropeiskykh krain / za red. Yermakova I. H. // Kroky do kompetentnosti ta intehratsii v suspilstvi. K.: «Kontekst», 2000.

17. Tatenko V. O. Lider XXI / Leader XXI. Sotsialno-psykholohichni studii. K. : Korporatsiia, 2004. $198 \mathrm{~s}$.

18. Chanyshev A. N. Aristotel / A. N. Chanyshev. 2-e izd., dop. M.: Mysl, 1987. $221 \mathrm{~s}$.

19. Boyatzis R. The competent manager. New York: Wiley, 2005. $406 \mathrm{p}$.

20. McClelland D. C. Testing for competence rather than for intelligence. American Psychologist. 1973. №28. P. 1-14.

\section{ОЛЬГА ШЕВАНДІНА}

магистрант Харьковского национального экономического университета имени

Семена Кузнеца, заведующая дошкольного учебного заведения №87, м. Харьков, Украина

\section{МАРИЯ АСТАХОВА}

кандидат педагогических наук, доцент кафедры педагогики, иностранной филологии и перевода Харьковского национального экономического университета имени Семена Кузнеца, м. Харьков, Украина

\section{УПРАВЛЕНИЕ ФОРМИРОВАНИЕМ ЛИДЕРСКОЙ КОМПЕТЕНТНОСТИ ПЕДАГОГИЧЕСКИХ РАБОТНИКОВ УЧРЕЖДЕНИЯ ДОШКОЛЬНОГО ОБРАЗОВАНИЯ}

Аннотация. Современное развитие общества выдвигает новые требования к педагогу, нуждается в развитии его духовного и лидерского потенциала. Сейчас растет спрос на креативную, нестандартно мыслящую личность, которая наделена силой воли, имеет лидерские качества, развитый «эмоциональный интеллект» и готова вести коллектив за собой. Именно личностное и профессиональное становление педагога-лидера обеспечит развитие образования как европейской социальной институции. Значительную роль в развитии общепрофессиональной компетентности педагога учреждения дошкольного образования играет формирование лидерской компетентности, а задача руководителя учебного заведения, в свою очередь, эффективно управлять этим процессом.

В статье рассмотрены взгляды ученых на содержание понятия «профессиональная компетентность» и «лидерская компетентность». Раскрыты сущностные характеристики лидерства в образовании. Охарактеризовано развитие профессионально значимых лидерских качеств и выделены 
Електронне наукове фахове видання «Адаптивне управління: теорія і практика. Серія «Педагогіка" Випуск 9(17), 2020

социально-психологические факторы, влияющие на профессиональную деятельность педагога-лидера.

Проанализировано образовательный процесс как объект управления и управления образовательной деятельностью учреждения дошкольного образования в условиях реформирования образования в Украине. Определено, что управление представляет собой сложный социально-экономический процесс и реализуется через определенные функции.

Особое внимание уделено раскрытию структуры процесса управления образовательной деятельностью учреждения дошкольного образования, представляющий собой управленческий цикл и реализующийся через общие функции управления. Созданы и исследованы составляющие системы управления лидерской компетентности и пути ее формирования, разработан инструментарий определения эффективности реализации системы управления лидерской компетентности педагогических работников заведения дошкольного образования.

Ключевые слова: компетентность, профессиональная компетентность, лидер, лидерская компетентность, управление качеством образования, система управления, заведение дошкольного образования.

\title{
OLHA SHEVANDINA,
}

Master`s degree student, Simon Kuznets Kharkiv National University of Economics, director, head of preschool №87, Kharkiv, Ukraine

\section{MARIIA ASTAKHOVA}

PhD (Pedagogical Sciences), Associate Professor of the Department of Pedagogy, Foreign Philology and Translation, Simon Kuznets Kharkiv National University of Economics. Kharkiv, Ukraine

\section{MANAGEMENT OF PRESCHOOL EDUCATORS`LEADERSHIP COMPETENCE FORMATION}

\begin{abstract}
Modern development of society sets new requirements to teachers and needs growth of its mental and leadership potential. Nowadays, in demand is creative original thinker, who has strong will power, leadership skills, well-developed emotional intelligence and is able to lead their staff. Personal and professional setting of teacher as leader enables development of education as all-European social institution. Leadership competence formation plays main role in general pre-school educators`competence development and that is why primary objective of the head of educational institution is to manage this process.
\end{abstract}

(C) Украӥнська інженерно-педагогічна академія

(С) ГО «Школа адаптивного управління соціально-педагогічними системами» (ㄱ Астахова М., Шевандіна О 
The article presents information about different points of view on the terms "professional competence" and "leadership competence". Integral characteristics of leadership in education are described. Development of professionally important leadership skills are characterized and social and psychological factors that influence on professional activity of teacher as leader are distinguished.

Educational process is analyzed as subject of management in general and as subject of preschool educational activity management under conditions of Ukrainian reformation of education. It is established, that management is complex socioeconomical process that is realized through several functions.

Structure of the preschool educational activity management process is underlined. It shows cycle of management and is realized through general management functions. Component parts of the leadership competence management system are created and researched with ways of its formation. Tools for defining effectiveness of preschool educators' leadership competence management system realization are developed.

Key words: competence, professional competence, leader, leadership competence, education quality management, management system, preschool. 